\title{
Early onset of organ failure is the best predictor of mortality in acute pancreatitis
}

\author{
I. Poves Prim, J. Fabregat Prous, F. J. García Borobia, R. Jorba Martí, J. Figueras Felip and E. Jaurrieta Mas \\ Department of General and Gastrointestinal Surgery. Hospital Prínceps d'Espanya. Citutat Sanitària i Universitària de \\ Bellvitge. L'Hospitalet de Llobregat. Barcelona. Spain
}

\begin{abstract}
Background: APACHE II is a multifactorial scoring system for predicting severity in acute pancreatitis (AP). Organ failure (OF) has been correlated with mortality in AP.

Objectives: to evaluate the usefulness of APACHE II as an early predictor of severity in AP, its correlation with $\mathrm{OF}$, and the relevance of an early establishment of OF during the course of AP.

Patients and methods: from January 1999 to November 2001, 447 consecutive cases of AP were studied. APACHE II scores and Atlanta criteria were used for defining severity and OF.

Results: twenty-five percent of patients had severe acute pancreatitis (SAP). APACHE II at $24 \mathrm{~h}$ after admission showed a sensitivity, specificity, and positive and negative predictive value of $52,77,46$, and $84 \%$, respectively, for predicting severity. Mortality for SAP was $20.5 \%$. Seventy percent of patients who developed OF did so within the first 24 hours of admission, and their mortality was $52 \%$. Mortality was statistically significant $(p<0.01)$ if OF was established within the first 24 hours after admission.

Conclusions: APACHE II is not reliable for predicting outcome within the first 24 hours after admission and should therefore be used together with other methods. OF mostly develops within the first days after admission, if ever. The time of onset of $\mathrm{OF}$ is the most accurate and reliable method for predicting death risk in $\mathrm{AP}$
\end{abstract}

Key words: Severe acute pancreatitis. Organ failure. APACHE II.

Poves Prim I, Fabregat Prous J, García Borobia FJ, Jorba Martí $R$, Figueras Felip J, Jaurrieta Mas E. Early onset of organ failure is the best predictor of mortality in acute pancreatitis. Rev Esp Enferm Dig 2004; 96: 705-713.

Recibido: 01-12-03.

Aceptado: 17-02-04.

Correspondencia: Ignasi Poves. Servicio de Cirugía General y Digestiva. Ciutat Sanitària i Universitaria de Bellvitge. C/ Feixa Llarga, s/n. 08907 L’Hospitalet de Llobregat. Barcelona. e-mail: 30023jpp@comb.es.

\section{INTRODUCTION}

The APACHE II scoring system (1) is the best illness grading system for quantifying severity in acute diseases. It is relatively easy to perform and its usefulness has been proved in the management of acute pancreatitis (AP) (2). In contrast to other scoring systems, it may be used since patient admission and during the whole course of disease. A good correlation between APACHE II scores and clinical outcome has been demonstrated in $\operatorname{AP}(3,4)$.

The International Symposium on AP held in Atlanta in 1992 promoted the use of the APACHE II scoring system, or other such as Ranson's, to evaluate disease severity. AP was considered severe if organ failure (OF) and/or local complications such as necrosis, abscess or pseudocyst were associated (5). Severe acute pancreatitis (SAP) was further characterized by eight or more points in the APACHE II score or three or more Ranson criteria.

This study aimed to assess the true usefulness of APACHE II as an early predictor of severity in patients with AP, the correlation of APACHE II scores with outcome and OF onset, and the relationship between mortality and early onset of OF in patients with SAP.

\section{PATIENTS AND METHODS}

Between January 1999 and November 2001 we studied 447 consecutive patients admitted to our hospital with a diagnosis of AP. This diagnosis was based on the presence of compatible clinical features and symptoms, and a serum amylase level over three times above normal (nor$\mathrm{mal}<2.16 \mathrm{ukat} / \mathrm{l})$, and/or a urine amylase level greater than $20 \mathrm{ukat} / \mathrm{l}$ (normal $<18 \mathrm{ukat} / \mathrm{l})$. Patients with a doubtful diagnosis and those whose initial diagnosis of pancreatitis was modified because of imaging studies were excluded. Patients with chronic pancreatitis were also excluded. 
The APACHE II score was calculated at admission, at $24 \mathrm{~h}$, at $48 \mathrm{~h}$, and then daily until clinical improvement or death. Physiological data (temperature, heart rate, blood pressure, and respiratory rate) were recorded at least every 6 hours, and the Glasgow Coma Scale was calculated daily. The APACHE II score was determined by using the most abnormal physiological and laboratory measurements during each $24 \mathrm{~h}$ period. In order to study early organ failure, patients were included if admitted within $48 \mathrm{~h}$ of symptom development.

A contrast-enhanced computed tomogram (CT) was performed if local complications were suspected (abdominal mass or tenderness, persistent abdominal pain, etc.), in the presence of clinical deterioration or OF, or when the diagnosis of AP was doubtful. Blood cultures and a CT-guided percutaneous fine-needle aspiration (PFNA) were performed when pancreatic infection was suspected (high fever and leukocytosis, OF or clinical deterioration).

The Atlanta classification system, which is based on clinical symptoms and radiological findings, was used to assess the severity of AP $(5,6)$. AP was considered severe when associated with OF (Table I) and/or local complications such as pancreatic necrosis, abscess, and large or multiple acute fluid collections. Necrosis was diagnosed by CT when involving at least 30\% of the pancreatic gland. Patients with initial hypoxia, transient hypotension or acute renal failure at admission -attributed to previous dehydration- who responded rapidly to therapy (fluid resuscitation) were not considered severe cases if pancreatic necrosis was not found on abdominal CT. A CT scan was performed at 72 hours after admission if the response to medical treatment was good. In those with a poor outcome a CT scan was carried out within the first 48 hours.

Surgical treatment was initially only indicated for patients with infected pancreatitis diagnosed by PFNA. Patients with sterile pancreatitis were all initially treated by organ dysfunction support, and surgical débridement was performed when intensive medical care was not effective.

Table I. Definition of organ failure according to criteria accepted in the Atlanta consensus conference

\begin{tabular}{|c|c|}
\hline Organ failure & Disturbance \\
\hline Circulatory shock & Systolic blood pressure < 90 mmHg \\
\hline Acute pulmonary failure & $\mathrm{PaO}_{2} \leq 60 \mathrm{mmHg}$ \\
\hline Acute renal failure & $\begin{array}{l}\text { Serum creatinine }>177 \mu \mathrm{mol} / \mathrm{L} \text { (> } 2 \\
\mathrm{mg} / \mathrm{dl} \text { ) after adequate fluid replace- } \\
\text { ment }\end{array}$ \\
\hline Gastrointestinal bleeding & $>500 \mathrm{ml} / 24 \mathrm{~h}$ \\
\hline $\begin{array}{l}\text { Disseminated intravascular } \\
\text { coagulation (DIC) }\end{array}$ & $\begin{array}{l}\leq 100,000 \text { platelets } / \mathrm{mm} \text {, or }<1 \mathrm{~g} \mathrm{fi-} \\
\text { brinogen/L, or PDF }>80 \mu \mathrm{g} / \mathrm{mL}\end{array}$ \\
\hline Severe calcium level disturbance & $<1.87 \mathrm{mmol} / \mathrm{L}(<7.5 \mathrm{mg} / \mathrm{dL})$ \\
\hline
\end{tabular}

The statistical analysis for comparing APACHE II data was performed using Student's t-test. Categorical variables were analyzed using Fisher's two-tailed exact test. A p-value $<0.05$ was considered significant for both.

\section{RESULTS}

\section{Etiology}

Factors involved in the etiology of AP included: gallstones in 266 patients (59.5\%), alcohol abuse in 61 (13.6\%), and other recognized factors (endoscopic cholangiopancreatography, drugs, neoplasm, etc.) in 34 (7.6\%). No associated factors were identified in 86 patients (19.3\%) during hospital stay.

\section{Severity}

According to the Atlanta classification system, 335 (75\%) patients suffered from mild AP and $112(25 \%)$ from SAP. Peak C-reactive protein (CRP) was $89 \pm 88$ and $277 \pm 111 \mathrm{mg} / \mathrm{l}$ within the first $48 \mathrm{~h}$ after admission for mild and severe AP, respectively. Of the 112 patients classified as having SAP, 57 developed OF, 62 necrotizing pancreatitis, and 100 multiple acute fluid collections.

\section{Surgical treatment}

Thirty-seven patients with SAP needed surgery. Indications for surgical treatment included: sepsis syndrome with positive blood cultures and/or PFNA in 27 patients (73\%), sterile pancreatitis with persistent OF or progressive clinical deterioration despite medical therapy in intensive care unit in seven patients $(18.9 \%)$, massive intraabdominal bleeding in two patients (5.4\%), and necrotizing pancreatitis from duodenal-pancreatic reflux caused by an upper intestinal obstruction (bezoar) in one patient $(2.7 \%)$.

Twenty patients were operated upon during the first week, eight during the second, four during the third, and five during or beyond the fourth week after admission (Fig. 1). Most patients operated on during the first week underwent surgery after the first 4 days of admission, and $65 \%$ had an infected necrotizing pancreatitis.

\section{APACHE II score}

In eight patients we were unable to fully calculate a complete APACHE II score at admission and at $24 \mathrm{~h}$ because of missing data (patients referred from other centers). Mean APACHE II score at admission and at 24 hours, and peak scores for mild and severe AP were $6.1 \pm 3.8,5.3 \pm 3.7$, $6.5 \pm 4$, and $8.6 \pm 4.8,9.1 \pm 5.1,12.2 \pm 6.3$, respectively. 


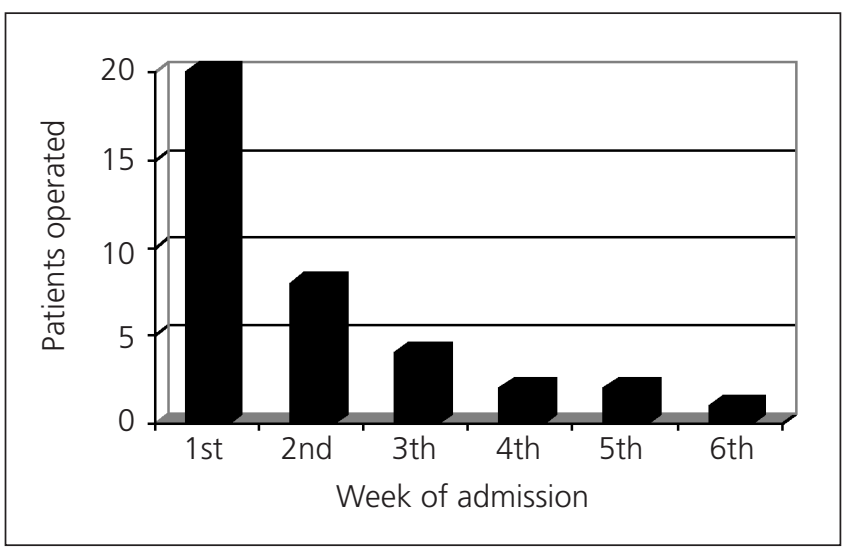

Fig. 1.- Timing for surgical treatment in patients with SAP. Momento del tratamiento quirúrgico en los pacientes con PAG.

While in mild AP peak scores were reached at $0.3 \pm 0.1$ days after admission (first $24 \mathrm{~h}$ ), in severe attacks they were reached at $4.1 \pm 7.8$ days (after $48 \mathrm{~h}$ ). Eighty-one percent (270/331) of patients with mild pancreatitis showed peak APACHE II scores at admission, while only $34.2 \%$ (37/108) with a severe attack did so. In all, 94\% (311/331) and $56.5 \%(60 / 108)$ of patients with mild and severe attacks, respectively, had a peak score within 24 hours of admission.

Thirty-seven percent (126/335) of patients with mild pancreatitis had a peak score $\geq 8$. One hundred and one of these were over 65 years of age, and seven had a severe chronic health status. In about $85 \%$ of patients with mild AP and APACHE II $\geq 8$, this score could be attributed to the additional weighting of age and chronic disease exclusively, not to inflammatory response.

Table II shows the sensitivity, specificity, and positive and negative predictive values of an APACHE II cut-off $\geq 8$ for detecting severity depending on the day after admission.

The APACHE II score at admission and at $24 \mathrm{~h}$, and the peak score were $10.4 \pm 5.2,11.3 \pm 5.4$, and $15.6 \pm 6.5$ for patients who had SAP with OF. In SAP without OF scores of $6.7 \pm 3.4,6.6 \pm 3.4$, and $8.4 \pm 3.2$, respectively, were recorded. These scores were statistically significant between groups depending of the presence of OF $(p<0.01)$.

\section{Outcome}

No deaths occurred in the mild pancreatitis group, and none of these patients had to be operated on. In contrast, the overall mortality rate was $20.5 \%$ (23/112) for SAP.
Mortality was $40.3 \%$ (23/57) and $0 \%(0 / 55)$ when SAP developed with or without OF, respectively. Causes of mortality included: thirteen patients had persistent multiple organ failure (MOF) not responding to intensive medical treatment and/or surgical therapy ( 9 sterile and 4 infected pancreatitis); five patients died from intractable acute respiratory distress syndrome; one from intracranial hemorrhage; two from persistent intra-abdominal sepsis; one from intra-abdominal diffuse hemorrhage, and one from upper gastrointestinal massive bleeding. Ten of these deaths occurred in elderly patients ( $>75$ years of age) with severe pre-existing co-morbidity (seven with severe heart failure and three with severe chronic respiratory failure). Four patients who died had morbid obesity, and one had chronic renal failure.

Nineteen patients presented with $\mathrm{OF}$ at admission, twenty-one developed it within the next $24 \mathrm{~h}$, nine between $24 \mathrm{~h}$ and $48 \mathrm{~h}$, and 8 after $48 \mathrm{~h}$ of admission. Mortality was higher in patients who developed OF within 24 hours of admission versus those whose OF was of later onset $(\mathrm{p}<0.01)$ (Table III).

Twenty-six of 37 operated on patients had preoperative OF. Mortality in these was $46 \%(12 / 26)$. None of the patients operated on without pre-operative $\mathrm{OF}$ died.

In sixteen of twenty-three patients who died, pancreatic necrosis was diagnosed on abdominal CT and/or operatively. Mortality was significantly higher in patients with pancreatic necrosis associated, varying from $25.8 \%$ $(16 / 62)$ to $14 \%(7 / 50)$.

\section{DISCUSSION}

AP is a complex disease that may remain localized in the pancreas, spread to regional tissues, or even involve distant organs (6). Microcirculatory disorders can be found not only in the pancreas, but also in the liver, colon, and lung $(7,8)$. AP is a disease with difficult-to-

Table III. Relationship between day of diagnosis of organ failure and mortality

\begin{tabular}{lcc}
\hline $\begin{array}{l}\text { Day of diagnosis of } \\
\text { organ failure }\end{array}$ & Patients & Mortality $n$ (\%) \\
\hline At admission & 19 & $11(58)$ \\
At 24 h & 21 & $10(47)$ \\
Between 24-48 h & 9 & $1(11)$ \\
After 48 h & 8 & $1(12.5)$ \\
\hline
\end{tabular}

Table II. Sensitivity, specificity, and positive and negative predictive value of an APACHE II score cut-off $\geq \mathbf{8}$ for detecting SAP

\begin{tabular}{lcccc}
\hline Apache $/ I \geq 8$ & Sensitivity (\%) & Specificity (\%) & Positive predictive value (\%) & Negative predictive value (\%) \\
\hline At admission & 60.2 & 65.6 & 36.3 & 83.7 \\
At 24 h & 52.7 & 76.8 & 46.3 & 84 \\
Peak score & 75.9 & 62 & 39.4 & 89 \\
\hline
\end{tabular}


prevent complications in patients identified as at risk (9). The search for early predictors of severity is motivated by a poor response to medical treatments available (10, 11). Supporting vital organs is the only effective medical treatment we know of $(12,13)$. A great number of predictors of severity, such as APACHE II (2-4) and contrastenhanced CT $(12,15,16)$, have been proposed, but their influence on prognosis improvement is unclear, and the results of SAP therapy are still discouraging.

Given that AP is considered a systemic disease, a number of scoring systems are useful to evaluate severity, as they are all based on physiological and biochemical variables. APACHE II is the multiple-scoring system with the highest accuracy in predicting severity $(3,4)$. Application of this system within the first $24 \mathrm{~h}$ may provide as good a prediction of severity as Ranson and Glasgow scores (17), but also a better follow-up throughout the course of disease. Recently, other methods for early prediction of severity have been reported (18). A new APACHE III prognostic system has been suggested to provide better risk stratification in severely ill hospitalized patients (19), but its advantages over APACHE II remain unclear (20). Neither serum polymorphonuclear elastase (21), nor urine trypsinogen activation peptide (TAP) provided accurate severity prediction as single markers 24 hours after symptom onset (22). In a multicenter study by Neoptolemos, the sensitivity, specificity, and positive and negative predictive values of urinary TAP at $24 \mathrm{~h}$ were $58,73,39$, and $86 \%$, respectively (23). These values are similar to those observed in our study for APACHE II at admission and at $24 \mathrm{~h}$. None of the reported early predictive factors are ideal, and all -including APACHE II, as demonstrated in our study- remain imperfect.

Mortality in AP is usually associated with systemic complications arising during the course of disease $(10,24)$. OF is the clinical manifestation of a severe systemic inflammatory response caused by a release of cytokines, free radicals and vasoactive molecules into the circulatory system $(25,26)$. Microcirculatory disorders in the pancreas and remote organ systems extend beyond the early stage of AP and can persist for more than $48 \mathrm{~h}$ (6). The mortality rate in patients with necrotizing pancreatitis is higher when OF is associated, and varies from 20 to $40 \%$ depending on the various series (27-30). The incidence of OF should be established by bacterial infection and extent of necrotic parenchyma in sterile necrosis (31). Beger et al. showed that pancreatic infection is more common during the late course of disease $(32,33)$. In these patients OF occurs long after admission. When sterile necrotizing pancreatitis is accompanied by OF, this complication usually develops soon after the onset of the disease $(27,31)$.

In our study we found data adding to the notion that the severity of the inflammatory process involving systemic organs in AP is established early during the first hours of disease. As has been proved in other studies
(29), there is a subgroup of patients with early SAP, defined as the presence of OF at admission, who more frequently develop intractable OF. Twenty-one of 23 patients who died developed OF within 24 hours or less. This is a very strong statement since the absence of OF within the first 24 hours ends up being a very good predictor of survival. As Buter et al. (34) reported, deteriorating organ dysfunction during the first week is a highly significant determinant of survival; in our opinion, however, the onset timing of $\mathrm{OF}$ is also extremely important. The later OF develops, the better the prognosis. Surgical treatment provides good control for local complications occurring in infected necrosis, but has not this same role for controlling systemic complications. Surgical treatment will be more effective if needed later. In order to obtain good results our desire is always to delay surgery when clinical conditions are favorable (supporting therapy, antibiotics and, in selected cases, percutaneous drainage). Unfortunately, this was not possible for most of our patients in need of surgery because of infected SAP or sterile SAP with uncontrollable OF, who had to be operated on within the first week of admission (Table II).

Considering, as the Atlanta consensus conference recommended, APACHE II $\geq 8$ points as predictive of severity in AP (5), this score showed a poor sensitivity, specificity, and positive predictive value. Such poor sensitivity was probably due to the added weight of age and chronic heath status. From our results, we consider that an APACHE II score cut-off value $\geq 8$ in patients without OF will probably not reflect severity in AP. No deaths were recorded in patients with a score $\geq 8$ and without OF; however, all patients with OF who died had a peak score $\geq 8$. These results are similar to those reported by Lankisch et al. (35), who concluded that APACHE II scores on admission were unreliable for diagnosing necrotizing pancreatitis; we obtained similar values for sensitivity, specificity, and positive and negative predictive value. Although APACHE II is considered the most precise scoring system for detecting severity in AP to date, and correlates well with SAP, it cannot be used alone. This system should be used together with clinical observations made by an expert physician and an evaluation of OF evidence.

$\mathrm{OF}$ is the main prognostic factor for detecting an unfavorable outcome and a high risk of death in AP. An APACHE II cut-off $\geq 8$ is not reliable for predicting outcome within the first $48 \mathrm{~h}$ of admission, and its main usefulness in AP is to serve as a model of reference for testing new predictive methods, and for comparing patients in inter-institutional series. Patients with SAP who develop OF within the first $24 \mathrm{~h}$ of admission are those with a worst prognosis and probably a fatal outcome. A strict follow-up of the parameters defined as $\mathrm{OF}$ in the Atlanta consensus within the first $24 \mathrm{~h}$ of admission is the most accurate and reliable method for predicting severity in AP, since the risk of mortality is greater than $50 \%$. 


\section{REFERENCES}

1. Knaus WA, Draper EA, Wagner DP, Zimmerman JE. APACHE II: a severity of disease classification system. Crit Care Med 1985; 13: 818-29.

2. Banks PA. Practice guidelines in acute pancreatitis. Am J Gastroenterol 1997; 92: 377-86.

3. Larvin M, McMahon MJ. APACHE II score for assessment and monitoring of acute pancreatitis. Lancet 1989; II: 201-4.

4. Wilson C, Heads A, Imrie CW. Prediction of outcome in acute pancreatitis: a comparative study of APACHE II, clinical assessment and multiple factor scoring systems. Br J Surg 1990; 77: 1260-4.

5. Bradley III E. A clinically based classification system for acute pancreatitis. Arch Surg 1993; 128: 586-90.

6. Banks PA. A new classfication system for acute pancreatitis. Am J Gastroenterol 1994; 89: 151-2.

7. Foitzik T, Eibl G, Hotz B, Hotz H, Kahrau S, Kasten C, et al. Persistent multiple organ microcirculatory disorders in severe acute pancreatitis: experimental findings and clinical implications. Dig Dis Sci 2002; 47: 130-8.

8. Mozo G, Del Olmo ML, Caro-Patón A, Reyes E, Manzano L, Belmonte A, et al. Lung changes and cytokine levels in a model of experimental acute pancreatitis. Rev Esp Enferm Dig 2002; 94: 53-66.

9. Beger HG, Rau B, Isenmann R. Prevention of severe change in acute pancreatitis: prediction and prevention. J Hepatobiliary Pancreat Surg 2001; 8: 140-7.

10. Banks PA. Acute pancreatitis: medical and surgical management. Am J Gastroentol 1994; 89: S78-85.

11. Wyncoll DL. The management of severe acute necrotizing pancreatitis: an evidence-based review of the literature. Intensive Care Med 1999; 25: 146-56.

12. Banks PA. Predictors of severity in acute pancreatitis. Pancreas 1991; 6 (Supl. 1): S7-S12.

13. Ribeiro MD, Paiva JA, Landeiro N, Duarte J. Patients with severe acute pancreatitis should be more often treated in an Intensive Care Department. Rev Esp Enferm Dig 2002; 94: 523-32.

14. Zhu AJ, Shi JS, Sun XJ. Risk factors influencing mortality of patients with severe acute pancreatitis within 24 hours after admission. Hepatobiliary Pancreat Dis Int 2003; 2: 453-7

15. Balthazar EJ, Robinson DL, Megibow AJ, Ranson JHC. Acute pancreatitis: value of CT in establishing prognosis. Radiology 1990; 174: 331-6.

16. Basterra G, Álvarez M, Marcaide A, Delgado E, Díaz de Otazu R, García Campos F. Acute pancreatitis: evaluation of the prognostic criteria of the latest Baltasar tomographic classification. Rev Esp Enferm Dig 1999; 91 : 433-8.

17. Johnson CD, Toh S. Prediction of severity in acute pancreatitis. In: Pancreatic disease, Towards the year. $2^{\text {nd }}$ ed. Springer, 2000.

18. Yadav D, Agarwal N, Pitchumoni CS. A critical evaluation of laboratory tests in acute pancreatitis Am J Gastroenterol 2002; 97: 1309-18.
19. Knaus WA, Wagner DP, Draper EA, Zimmerman JE, Bergner M, Bastos PG, et al. The APACHE III prognostic system. Risk prediction of hospital mortality for critically ill hospitalized patients. Chest 1991; 100: 1619-36.

20. Chatzicostas C, Roussomoustakaki M, Vlachonikolis IG, Notas G, Mouzas I, Samonakis D, et al. Comparison of Ranson, APACHE II and APACHE III scoring systems in acute pancreatitis. Pancreas 2002; 25: 331-5.

21. Luengo L, Castellote M, Ros S, Feliu F, Vadillo J, Olona C. Clinical usefulness of the determination of the lipase/elastase ratio and of the polymorphonuclear elastase in the hospital admission of the patient with acute pancreatitis. Rev Esp Enferm Dig 1996; 88: 551-4.

22. Tenner S, Fernández-del Castillo C, Warshaw A, Steinberg W, HermonTaylor J, Valenzuela JE, et al. Urinary trysinogen activation peptide (TAP) predicts severity in patients with acute pancreatitis. Int J Pancreatol 1997; 21: $105-10$.

23. Neoptolemos JP, Kemppainen EA, Mayer JM, Fitzpatrick JM, Raraty MG, Slavin J, et al. Early prediction of severity in acute pancreatitis by urinary trypsinogen activation peptide: a multicentre study. Lancet 2000; 355 (9219): 1955-60.

24. Bradley EL. Necrotizing pancreatitis. Br J Surg 1999; 86: 147-8

25. Norman J. The role of cytokines in the pathogenesis of acute pancreatitis. Am J Surg 1998; 175: 76-83.

26. Karne S, Gorelick F. Etiopathogenesis of acute pancreatitis. Surg Clin North Am 1999; 79: 699-710.

27. Rau B, Pralle U, Uhl W, Schoenberg MH, Beger HG. Management of sterile necrosis in instances of severe acute pancreatitis. J Am Coll Surg 1995; 181: 279-88.

28. Poves I, Fabregat J, Biondo S, Jorba R, Borobia FG, Llado L, et al. Results of treatment in severe acute pancreatitis. Rev Esp Enferm Dig 2000; 92 : 586-90.

29. Isenmann R, Rau B, Beger HG. Early severe acute pancreatitis: characteristics of a new subgroup. Pancreas 2001; 22: 274-8.

30. Soran A, Chelluri L, Lee KK, Tisherman SA. Outcome and quality of life of patients with acute pancreatitis requiring intensive care. J Surg Res 2000; 91: 89-94.

31. Isenmann R, Rau B, Beger HG. Bacterial infection and extent of necrosis are determinants of organ failure in patients with acute necrotizing pancreatitis. Br J Surg 1999; 86: 1020-4.

32. Beger HG, Bittner R, Block S, Büchler M. Bacterial contamination of pancreatic necrosis. A prospective clinical study. Gastroenterology 1986; 91 : 433-8.

33. Beger HG, Rau B, Mayer J, Pralle U. Natural course of acute pancreatitis World J Surg 1997; 21: 130-5.

34. Buter A, Imrie CW, Carter CR, Evans S, McKay CJ. Dynamic nature of early organ dysfunction determines outcome in acute pancreatitis. $\mathrm{Br} \mathrm{J}$ Surg 2002; 89: 289-302.

35. Lankisch PG, Warnecke B, Bruns D, Werner HM, Grossmann F, Struckmann $\mathrm{K}$, et al. The APACHE II score is unreliable to diagnose necrotizing pancreatitis on admission to hospital. Pancreas 2002; 24: 217-22.

\title{
El fracaso orgánico precoz como mejor factor predictivo de mortalidad en la pancreatitis aguda
}

\author{
I. Poves Prim, J. Fabregat Prous, F. J. García Borobia, R. Jorba Martí, J. Figueras Felip y E. Jaurrieta Mas \\ Servicio de Cirugía General y del Aparato Digestivo. Hospital Prínceps d'Espanya. Citutat Sanitària i Universitària de \\ Bellvitge. L'Hospitalet del Llobregat. Barcelona
}

\section{RESUMEN}

Introducción: el APACHE II se ha utilizado como factor predictivo de gravedad en la pancratitis aguda (PA). La instauración de fracaso orgánico (FO) en la PA se correlaciona con una mayor mortalidad.
Objetivos: evaluar la utilidad del APACHE II como factor predictivo precoz de gravedad en la PA, su correlación con el FO y la relevancia del establecimiento precoz del FO en la PA.

Pacientes y métodos: desde enero de 1999 hasta noviembre de 2001 se estudiaron 447 pacientes ingresados consecutiva- 
mente por PA. Se utilizó el sistema APACHE II y los criterios de Atlanta para evaluar la gravedad.

Resultados: el 25\% de los pacientes presentaron una pancreatitis aguda grave (PAG). El APACHE II a las 24 horas del ingreso mostró una sensibilidad, especificidad, valor predictivo positivo y negativo del $52,77,46$ y $84 \%$, respectivamente, como marcador de gravedad. La mortalidad global de la PAG fue del 20,5\%. El $70 \%$ de los pacientes que presentaron $\mathrm{FO}$ lo hicieron en las primeras 24 horas del ingreso, falleciendo el 52\% de ellos. La mortalidad fue significativamente mayor $(p<0,01)$ si el FO se estableció en ese periodo.

Conclusiones: el APACHE II por si solo no es un sistema fiable de detección precoz de gravedad en las primeras 24 horas del ingreso por lo que debe utilizarse junto con otros métodos. El FO suele establecerse en los primeros días del curso evolutivo de la PA. La precocidad del establecimiento del FO muestra una estrecha relación con la mortalidad en la PA.

Palabras clave: Pancreatitis aguda grave. Fracaso orgánico. APACHE II

\section{INTRODUCCIÓN}

El sistema APACHE II (1) es un sistema de evaluación de gravedad para procesos agudos, relativamente sencillo de realizar, que ha mostrado utilidad en la valoración de severidad de la pancreatitis aguda (PA) (2). A diferencia de otros métodos, puede utilizarse desde el momento del ingreso y durante todo el curso evolutivo de la enfermedad. En la PA se ha demostrado una estrecha relación entre la evolución clínica y los registros de puntuación APACHE II $(3,4)$.

La reunión internacional de expertos de Atlanta en 1992 promovió la generalización del uso del APACHE II en la evaluación de gravedad de la PA. En dicha reunión se consideró que la PA cumplía criterios de gravedad si se asociaba fracaso orgánico (FO) y/o complicaciones locales tales como necrosis pancreática, absceso o pseudoquistes (5). La pancreatitis aguda grave (PAG) se caracterizaría por presentar ocho o más puntos en el sistema APACHE II.

El objetivo del estudio es evaluar la utilidad real del sistema APACHE II como factor pronóstico precoz de gravedad en la PA correlacionando sus puntuaciones con el curso evolutivo de la enfermedad y la existencia de FO, así como evaluar la relación entre la mortalidad y establecimiento precoz de $\mathrm{FO}$ en los pacientes que presenten una PAG.

\section{PACIENTES Y MÉTODOS}

Desde enero de 1999 a noviembre de 2001, ingresaron consecutivamente en nuestro centro 447 pacientes con el diagnóstico de PA. El diagnóstico se realizó en base a la presentación de un cuadro clínico compatible junto a la elevación de los valores séricos de amilasa tres veces por encima de lo normal (normal $<2,16 \mathrm{ukat} / \mathrm{l}$ ) y/o valores de amilasa en orina superiores a 20 ukat/l (normal $<18$ ukat/l). Los pacientes con diagnóstico dudoso o cuyo diagnóstico final se modificó en base a otros hallazgos y aquellos con pancreatitis crónica se excluyeron del estudio.

La puntuación APACHE II se calculó al ingreso, a las $24 \mathrm{~h}$, a las $48 \mathrm{~h}$ y diariamente hasta presentar mejoría clínica o fallecer. Los parámetros fisiológicos (temperatura, frecuencia cardiaca, tensión arterial y frecuencia respiratoria) se registraron cada 6 horas y la escala de coma de Glasgow una vez al día. La puntuación diaria APACHE II se calculó en base a los registros más anormales durante las 24 horas. Para estudiar el FO precoz, se incluyeron sólo los pacientes que acudieron a urgencias dentro de las primeras 48 horas desde el inicio de los síntomas.

Se realizó una tomografía computadorizada (TC) abdominal ante la sospecha de complicaciones locales, en caso de deterioro clínico, existencia de FO o cuando el diagnóstico de PA era dudoso. Se practicaron hemocultivos y punción aspiración con aguja fina guiada por TC (PAAF) ante la sospecha de infección pancreática (fiebre alta con leucocitosis, FO o deterioro clínico).

Se utilizó la clasificación de Atlanta, basada en hallazgos clínicos y radiológicos, para determinar la gravedad de la PA $(5,6)$. La PA se consideró grave cuando se asoció FO (Tabla I) y/o complicaciones locales. Aquellos pacientes con hipoxemia inicial, hipotensión transitoria o insuficiencia real aguda en el momento del ingreso, atribuida a deshidratación previa y que respondieron rápida y eficazmente a la reposición hidroelectrolítica, no se consideraron como PAG si no se hallaron complicaciones locales en la TC.

Se indicó tratamiento quirúrgico en los pacientes que presentaron una pancreatitis infectada diagnosticada por PAAF y en aquellos que presentaron una PAG estéril con evolución catastrófica y disfunción orgánica severa a pesar del tratamiento médico intensivo de soporte.

Se utilizó el test estadístico de la t de Student para comparar las puntuaciones del APACHE II. Para el estu-

\section{Tabla I. Definición de fracaso orgánico según los criterios} aceptados en la conferencia de consenso de Atlanta

\begin{tabular}{|c|c|}
\hline Fracaso orgánico & Hallazgo clínico \\
\hline Colapso circulatorio & Presión arterial sistólica $<90$ mmHg \\
\hline Insuficiencia respiratoria aguda & $\mathrm{PaO}_{2} \leq 60 \mathrm{mmHg}$ \\
\hline Insuficiencia renal aguda & $\begin{array}{l}\text { Creatinina sérica }>177 \mu \mathrm{mol} / \mathrm{L} \text { (> } 2 \\
\text { mg/dl) después de adecuada reposi- } \\
\text { ción de líquidos }\end{array}$ \\
\hline Hemorragia gastrointestinal & $>500 \mathrm{ml} / 24 \mathrm{~h}$ \\
\hline Coagulación intravascular & $\leq 100.000$ plaquetas $/ \mathrm{mm} \mathrm{o}<1 \mathrm{~g} \mathrm{fi-}$ \\
\hline Diseminada (CID) & brinogeno/L, o PDF > $80 \mu \mathrm{g} / \mathrm{mL}$ \\
\hline Hipocalcemia severa & $<1,87 \mathrm{mmol} / \mathrm{L}(<7,5 \mathrm{mg} / \mathrm{dl})$ \\
\hline
\end{tabular}


dio de las variables cualitativas se utilizó test exacto de Fisher's. En ambos tests, se consideró que las diferencias eran significativas si la $\mathrm{p}<0,05$.

\section{RESULTADOS}

\section{Etiología}

Las causas etiológicas de PA durante el ingreso fueron: litiasis biliar y/o coledocal en 266 pacientes $(59,5 \%)$, idiopática en $86(19,3 \%)$, alcohol en $61(13,6 \%)$ y otros factores reconocibles (colangiopancreatografía retrógrada endoscópica, fármacos, neoplasia, etc.) en 34 (7,6\%).

\section{Criterios de gravedad}

Según la clasificación de Atlanta, el 75\% de los casos (335 pacientes) fueron PA leves y el 25\% graves (112 pacientes). El pico máximo de proteína $\mathrm{C}$ reactiva $(\mathrm{PCR})$ en las primeras 48 horas del ingreso fue de $89 \pm 88$ y $277 \pm$ $111 \mathrm{mg} / \mathrm{l}$, respectivamente para la PA leve y grave. En los pacientes con PAG, 57 presentaron FO, 62 necrosis pancreática y 100 colecciones agudas múltiples.

\section{Tratamiento quirúrgico}

Se operaron 37 pacientes por PAG. Las indicaciones para tratamiento quirúrgico fueron: sepsis con hemocultivos y/o PAAF positiva en 27 pacientes (73\%), pancreatitis estéril con FO persistente o deterioro clínico progresivo a pesar del tratamiento médico intensivo en 7 pacientes $(18,9 \%)$, hemorragia intraabdominal masiva en 2 pacientes $(5,4 \%)$ y $1(2,7 \%)$ paciente por presentar una oclusión intestinal por bezoar duodenal que era la causa de la PAG.

Veinte pacientes se operaron en la primera semana del ingreso, ocho en la segunda, cuatro en la tercera y cinco a partir de la cuarta (Fig. 1). El 65\% de los pacientes operados en la primera semana del ingreso presentaban una infección de la necrosis pancreática.

\section{Puntuación APACHE II}

En 8 pacientes no se pudo registrar la puntuación APACHE II en el ingreso y a las 24 horas. La puntuación APACHE II media al ingreso, en las primeras 24 horas y la puntuación pico máxima fue de $6,1 \pm 3,8,5,3 \pm 3,7,6,5$ \pm 4 , y $8,6 \pm 4,8,9,1 \pm 5.1,12,2 \pm 6,3$, respectivamente para la PA leve y grave. Mientras que en la PA leve el pico máximo se alcanzó en las primeras 24 horas del ingreso (0,3 $\pm 0,1$ días), en la PAG este se alcanzó pasadas las primeras 48 horas del mismo (4,1 \pm 7,8 días). El pico máximo del APACHE II se presentó en el momento del ingreso en el $81 \%$ (270/331) y 34\% (37/108) de los pacientes con una PA leve y grave, respectivamente. Si se tienen en cuenta las primeras 24 horas del ingreso, la puntuación pico se obtuvo en el 94\% (311/331) y el 56\% (60/108) de los pacientes con una PA leve y grave, respectivamente.

El 37\% (126/335) de los pacientes con una PA leve tuvieron una puntuación pico $\geq 8$. Ciento uno de esos pacientes tenían más de 65 años y otros siete enfermedades crónicas graves asociadas. En el $85 \%$ de los pacientes con una PA leve y APACHE II $\geq 8$, se pudo atribuir esta elevada puntuación exclusivamente al valor específico que representa la edad y el estado previo de enfermedad crónica, no a la respuesta inflamatoria o gravedad de la PA.

En la tabla II se muestra la sensibilidad, especificidad, valor predictivo positivo y negativo del sistema APACHE II como factor predictivo de gravedad para un punto de corte $\geq 8$ puntos y según el tiempo de evolución desde el ingreso.

La puntuación APACHE II al ingreso, a las $24 \mathrm{~h}$ y el pico máximo fueron de $10,4 \pm 5,2,11,3 \pm 5,4$ y $15,6 \pm 6,5$ para aquellos pacientes que presentaron una PAG con FO. En aquellos con PAG sin FO las puntuaciones registradas fueron de $6,7 \pm 3,4,6,6 \pm 3,4$ y $8,4 \pm 3,2$. Las diferencias en estas puntuaciones fueron estadísticamente significativas entre ambos grupos dependiendo de la presencia o no de FO $(\mathrm{p}<0,01)$.

\section{Evolución y seguimiento}

No hubo ninguna muerte en el grupo de la PA leve y ninguno de estos pacientes tuvo que ser operado. La mortalidad global de la PAG fue del 20,5\% (23/112). La mortalidad osciló entre un 40,3\% (23/57) y un $0 \%(0 / 55)$ dependiendo de si, respectivamente, se estableció FO o no. Las causas de las muertes fueron: 13 por fracaso orgánico múltiple (FOM) sin respuesta al tratamiento médico intensivo ni al quirúrgico (9 PA estériles y 4 infectadas); 5 por insuficiencia respiratoria aguda intratable; 1 por hemorragia cerebral; 2 por sepsis intraabdominal persisten-

Tabla II. Sensibilidad, especificidad, valor predictivo positivo y negativo para un valor de corte del APACHE II $\geq 8$ para detectar PAG

\begin{tabular}{lcccc}
\hline Apache $/$ I $\geq 8$ & Sensibilidad (\%) & Especificidad (\%) & Valor predictivo positivo (\%) & Valor predictivo negativo (\%) \\
\hline Al ingreso & 60,2 & 65,6 & 36,3 & 83,7 \\
A las 24 h & 52,7 & 76,8 & 46,3 & 84 \\
Puntuación pico máxima & 75,9 & 62 & 39,4 & 89 \\
\hline
\end{tabular}


te; 1 por hemorragia intraabdominal difusa y 1 por hemorragia digestiva alta masiva. Diez de los pacientes fallecidos eran ancianos (más de 75 años) con enfermedad crónica grave asociada ( 7 padecían de insuficiencia cardiaca y 3 de insuficiencia respiratoria crónica severa). Cuatro de los otros pacientes que fallecieron presentaban una obesidad mórbida y uno una insuficiencia renal crónica.

Diecinueve pacientes presentaron FO en el momento del ingreso, veintiuno en las siguientes 24 horas, nueve entre las 24 y 48 horas del ingreso y ocho después de las primeras 48 horas del ingreso. La mortalidad fue significativamente mayor en aquellos pacientes en los que el FO se estableció en las primeras 24 horas del ingreso ( $\mathrm{p}<$ $0,01)$ (Tabla III).

Veintiseis de los 37 pacientes operados presentaron FO previo. La mortalidad en estos fue del $46 \%$ (12/26). Ninguno de los pacientes operados sin FO previo falleció.

Tabla III. Relación entre el día de establecimiento del FO y la mortalidad

\begin{tabular}{lcc}
\hline $\begin{array}{l}\text { Día de establecimiento } \\
\text { del fracaso orgánico }\end{array}$ & Pacientes & Mortalidad $n$ (\%) \\
\hline Al ingreso & 19 & $11(58)$ \\
A las 24 h & 21 & $10(47)$ \\
Entre las 24-48 h & 9 & $1(11)$ \\
Después de 48 h & 8 & $1(12,5)$ \\
\hline
\end{tabular}

\section{DISCUSIÓN}

La PA es una enfermedad compleja que puede afectar tanto al páncreas, como a órganos adyacentes y a distancia (6), demostrándose por alteraciones en la microvascularización tanto del páncreas, como del hígado, colon y pulmones (7) y cuyas complicaciones son difíciles de prevenir (8). Debido a la poca efectividad del tratamiento médico surge la necesidad de utilizar factores de predicción precoz de mala evolución $(9,10)$. El soporte de órganos vitales es el único tratamiento que se ha demostrado efectivo. Ninguno de los factores pronósticos de gravedad habitualmente utilizados, APACHE II (2-4) y la TC abdominal $(11,12)$, han demostrado tener influencia clara en mejorar el pronóstico final en la PAG.

Dado que la PA es una enfermedad sistémica, se han propuesto sistemas de puntuación basados en parámetros fisiológicos y bioquímicos para evaluar la gravedad del proceso, siendo el APACHE II uno de los más fiables $(3,4)$. Su aplicación ya desde las primeras 24 horas del ingreso permite, además de equipararse en fiabilidad a otros como los criterios de Ranson o Glasgow (13), un mejor seguimiento durante todo el curso clínico del proceso. No obstante, sigue siendo impreciso por lo que se siguen comunicando otros nuevos (14). El sistema APACHE III, propuesto para mejorar la estratificación del riesgo en los pacientes hospitalizados graves (15), no ha demostrado beneficios respecto al APACHE II (16). La determinación en orina del péptido activador del tripsinógeno (TAP) ha mostrado una adecuada predicción de gravedad, como marcador único, pasadas 24 horas después del inicio de los síntomas (17). En el estudio multicéntrico de Neoptolemos y cols., la sensibilidad, especificidad, valor predictivo positivo y negativo del TAP urinario a las 24 horas fueron del 58, 73, 39 y 86\%, respectivamente (18). Estos valores son similares a los obtenidos en nuestro estudio para el APACHE II al ingreso y a las 24 horas. Ninguno de los factores de predicción precoz de gravedad comunicados se ha mostrado como el ideal y todos ellos, incluido el APACHE II, como hemos demostrado, muestran carencias.

La mortalidad en la PA suele atribuirse a las complicaciones sistémicas $(9,19)$. El FO representa la manifestación clínica de la respuesta sistémica inflamatoria causada por la liberación masiva de sustancias vasoactivas a la circulación sistémica $(20,21)$. Las alteraciones en la microcirculación de los órganos afectados aparecen desde la instauración del proceso y pueden persistir más de 48 horas (6). Se ha demostrado que la mortalidad en los pacientes con necrosis pancreática es mayor si se asocia FO, variando entre un 20 y $40 \%$ dependiendo de las series (22-25). La aparición del FO se determinaría tanto por la existencia de infección bacteriana, como por la extensión de la necrosis pancreática estéril (26). Los trabajos clásicos de Beger parecían mostrar que la infección pancreática sucedía predominantemente en fases tardías de la enfermedad $(27,28)$. En estos pacientes, el FO aparecería en fases tardías del ingreso. En cambio, cuando el FO se instaura en una pancreatitis estéril, suele hacerlo en las fases tempranas de la enfermedad $(22,26)$.

Los hallazgos de nuestro estudio corroboran el hecho que la severidad del proceso inflamatorio que afecta a órganos lejanos en la PA se establece en las primeras horas del curso de la enfermedad. Como se ha demostrado en otros estudios (24), existe un subgrupo de pacientes que presentan una PAG en la que el FO se instaura de forma precoz, estando generalmente presente en el momento del ingreso, y que suele ser intratable y de pronóstico infausto. Veintiuno de los veintitrés pacientes de nuestra serie que fallecieron presentaron FO en las primeras 24 horas del ingreso. En base a nuestros resultados, la ausencia de FO en las primeras 24 horas del ingreso resultaría como un factor predictivo de supervivencia muy fiable. Según Buter y cols. (29), el deterioro de la disfunción orgánica durante la primera semana del ingreso sería determinante de supervivencia; pero más aún, en nuestra opinión, el momento del establecimiento del FO sería el factor más importante. 
Cuanto más tarde se establece el FO, mejor es el pronóstico. El tratamiento quirúrgico, efectivo para el manejo de las complicaciones locales que suceden en la necrosis infectada, deja de serlo para el control de las complicaciones sistémicas. Cuanto más tardíamente se precise realizar el desbridamiento quirúrgico, más efectivo será este. Desafortunadamente, en nuestra serie, la mayoría de los pacientes operados, tuvieron que ser sometidos a desbridamiento quirúrgico en la primera semana del ingreso (Tabla II).

Considerando una puntuación APACHE II $\geq 8$ puntos como predictiva de gravedad en la PA (5), en nuestro grupo de pacientes este punto de corte mostró una mala sensibilidad, especificidad y valor predictivo positivo. Esta pobre sensibilidad probablemente se pueda atribuir al excesivo peso que tiene la edad avanzada y el estado crónico preexistente de salud en la puntuación final del APACHE II. Según nuestros resultados, consideramos que el punto de corte del APACHE II $\geq 8$ no refleja la severidad del proceso en los pacientes sin FO. Ningún paciente sin FO y con una puntuación $\geq 8$ falleció, en cambio, todos los pacientes que presentaron FO que murieron obtuvieron puntuaciones máximas pico $\geq$
8. Estos resultados consolidan las conclusiones descritas por Lankisch y cols. (30), respecto a que la puntuación APACHE II en el momento del ingreso no sería determinante para el diagnóstico de necrosis pancreática. En nuestra opinión, el APACHE II no debe ser utilizado aisladamente, sino que debe apoyar la valoración clínica y la cuidadosa búsqueda de signos de FO.

El FO es el principal factor pronóstico para detectar evolución desfavorable y riesgo de muerte en la PA. Una puntuación corte del APACHE II $\geq 8$ no es fiable para predecir la evolución en las primeras 48 horas del ingreso, siendo su principal utilidad en la PA la de servir como modelo de referencia para nuevos métodos predictivos y para comparación interinstitucional de distintas series. Los pacientes que presentan una PAG con instauración del FO en las primeras 24 horas del ingreso son aquellos que tendrán un peor pronóstico y evolución desfavorable. Un estricto seguimiento de los parámetros de FO, definidos en la conferencia de consenso de Atlanta, durante las primeras 24 horas del ingreso es el método más fiable y adecuado para predecir gravedad en la PA, siendo el riesgo de muerte superior al $50 \%$ en estos casos. 